\title{
Work Ethics, Work Satisfaction and Organizational Commitment at the Sharia Bank, Indonesia
}

\author{
Nurul Komari ${ }^{1} \&$ Fariastuti Djafar ${ }^{2}$ \\ ${ }^{1}$ Faculty of Economics, Universitas Tanjungpura, Indonesia \\ ${ }^{2}$ Faculty of Economics and Business, Universiti Malaysia Sarawak, Malaysia \\ Correspondence: Fariastuti Djafar, Faculty of Economics and Business, Universiti Malaysia Sarawak (UNIMAS), \\ 94300 Kota Samarahan, Sarawak, Malaysia. Tel: 608-258-1000. E-mail: dfariastuti@feb.unimas.my
}

Received: September 12, 2013

Accepted: October 10, 2013

Online Published: November 22, 2013

doi: 10.5539/ibr.v6n12p107

URL: http://dx.doi.org/10.5539/ibr.v6n12p107

\begin{abstract}
The objective of this study is to examine the effect of work ethics on work satisfaction and organizational commitment at the Sharia Bank. As many as 78 employees became respondents in the study. The data were obtained by utilizing a self-administered questionnaire and in-depth interviews, and analysed using Partial Least Squares (PLS). The findings in the study show that work ethics has a non-significant negative effect on work satisfaction while work ethics has a significant positive effect on organizational commitment. This study concludes that work ethics are very important for organizational commitment but that they cannot automatically create high job satisfaction. Work ethics and work satisfaction are not necessarily related, which might be due to the perception of fairness among the employees.
\end{abstract}

Keywords: work ethics, work satisfaction, organizational commitment, Sharia bank

\section{Introduction}

Beyond salary, work ethics is able to influence human beings to commit or not to commit a crime. In March 2011, the Indonesian public were shocked by the detention by the police of a Senior Relationship Manager of Citibank in Jakarta. The former manager was charged with conducting illegal transactions. Having a total compensation of more than 500 million rupiahs (RP.) per year (1 USD was approximately equal to Rp. 9,500 in 2012) was not able to prevent her from undertaking transactions on behalf of customers for her own personal needs. Less than two years later, in August 2012, the Indonesian public were surprised when a 35 year old office boy working at Bank Syariah Mandiri, Bekasi, Indonesia, returned Rp. 100 million he found on the floor of his office to the bank. The money represents a considerable sum for a father of three children who had been working for three years for a salary of Rp. 2.2 million per month. Nevertheless, his personal circumstances did not cause him to take the money for his own personal needs. These two contradictory cases illustrate the lesson that a high salary is not sufficient to prevent people being corrupt while a low salary does not necessarily lead to corruption.

Work ethics is important in today's business because employee's behaviour strongly contributes to the success of an organization in the global market (Ali \& Azim, 1995; Valentine \& Barnett, 2007). The crimes committed by employees may cause the company's image to rapidly deteriorate. This is evidenced by the case of Enron, which recorded one of the largest corporate bankruptcies in the history of the United States of America (USA), arising from the high risk of accounting practice. Many studies have been conducted on the effect of work ethics on job satisfaction and organizational commitment and the findings are mixed. Some researchers reported a positive and significant effect of work ethics on job satisfaction (eg., Koh \& Boo, 2004; Okpara \& Wynn, 2008) and organizational commitment (eg., Ali \& Al-Kazemi, 2007; Mohamed, Karim \& Hussein, 2010). In contrast, other researchers found that the effect of work ethics on job satisfaction is weakly significant (eg., Elkins, 2007) or negative and significant (Arifuddin, 2002). In addition, work ethics may not have any influence on organizational commitment (Uygur, 2009).

Previous studies concentrated more on work attitudes than work ethics (Valentine, Golkin, Fleischman \& Kidwell, 2011), while limited studies have been conducted on organizational commitment, which has an important influence on organizational development (Cullen, Parboteeah, \& Victor, 2003; Kurpis, Begiri \& Helgeson, 2008; Valentine et al., 2011). Elci, Sener and Alpkan (2011) recommend that organizational 
commitment should be included in future research. Given these considerations, the main objective of this study is to examine the effect of work ethics on job satisfaction and organizational commitment. This study contributes to the empirical literature on the relationship of work ethics with job satisfaction and organizational commitment. This study also contributes to the Islamic literature since Indonesia is the largest Moslem country in the world. This paper is presented as follows. The next section discusses the review of the literature, which is followed by an explanation of the research design in section 3, analysing empirical findings in section 4 , and, finally, discussion and conclusion are presented in section 5 .

\section{Literature Review}

Work ethics in the organization is the key to the ethical behaviour of employees. Organizations that focus on developing work ethics relevant to the issues faced by employees will lead to the employees behaving ethically (Valentine \& Barnett, 2007). Practicing work ethics is an effective means for improving the performance of an organization, especially when the organization uses different approaches in creating an ethical culture among the employees (Valentine et al., 2011). Previous studies have measured work ethics with a variety of indicators. The indicators include self-interest, company profit, efficiency, team attention, social responsibility, personal morality, company rules and procedures, laws, codes of conduct (Elzi \& Alpkan, 2009); wise and egoist attitudes (Cullen et al., 2003); communication, training and training duration, codes of ethics (Valentine \& Fleischman, 2008); caring, law and ethics, instrumentality, regulatory, autonomy (Victor \& Cullen, 1988); working as a goal, time utilization and hard work (Ali, 1988). Work ethics help prevent problems that will be detrimental to the organization and employees (Yousef, 2001).

\subsection{Relationship between Work Ethics and Job Satisfaction}

Many factors influence job satisfaction. These factors include social, psychological and financial aspects (Jewell, 1998); peer and supervisor support (Gu \& Siu, 2009); the work itself, wage or salary, supervision, promotion opportunities, team work (Luthans, 2006); tension arising from labour relations, intrinsic motivation, confidence in the abilities of management (Leat \& El-Kot, 2009); personal health, the quality of life, personal development, and relationships among co-workers, and between the supervisors and employees (Chileshe \& Haupt, 2010). Organizations must pay attention to employees continuously in respect of their work satisfaction and their better job performance and health (Khan, Farooq \& Hussain, 2010). Job satisfaction is not only a reflection of the success or failure of an employee's life but also influences the employee's attitude and their life. Better attitudes and the improved quality of life of employees will lead to a successful organization (Locke, Latham \& Erez, 1988).

The significantly positive effect of work ethics on job satisfaction in the religious context has been studied by many researchers. This is reported by researchers studying the effect of Islamic work ethics on job satisfaction among academic staff in Malaysia (Mohamed et al., 2010); employees in manufacturing and services companies in Arab countries (Yousef, 2000) and in microfinance organizations in Indonesia (Rokhman, 2010). The same findings have also been identified by researchers studying the influence of Confucian work ethics among managers in Singapore and Protestant work ethics among managers in the USA concerning job satisfaction (Williams \& Sandler, 1995; Cullen et al., 2003).

Previous studies also examined the effect of work ethics on job satisfaction based on organizational culture, especially leadership style. Practicing work ethics among top management and supervisors, such as talking about work ethics in the office, keeping a promise and a commitment, looking after employees and becoming a model for ethical behaviour will create satisfaction for most of the employees. Job satisfaction among employees will decline if top management and supervisors are least likely to practice work ethics (Coldwell et al., 2008). A study in Singapore by Koh and Boo (2004) revealed the significantly positive effect of top management support for ethical behaviour on job satisfaction.

Different indicators of work ethics may have different effects on job satisfaction among the same respondents. A study among 1,174 staff and managers from 62 telecom companies in Turkey found that self-interest had a negative effect, and that team's attention, social responsibility, regulatory, legal and ethics code had a positive effect on job satisfaction (Elci \& Alpkan, 2009). Similarly, Ahmed, Shad, Mumtaz and Tanveer (2012) reported that, in Pakistan, an ethical climate principle is not related to job satisfaction among employees in private and government organizations while an egoist attitude is negatively related and wise management and ethics are positively related to job satisfaction.

The effects of work ethics on job satisfaction may differ between groups. Organizations developing work ethics based on religious values will lead to job satisfaction among employees having and applying a religious belief (Yousef, 2000). Elkins (2007), in his study among Japanese manufacturing companies in the USA, reported a 
weak relationship between work ethics and job satisfaction among permanent and temporary employees, while employees with a fixed salary have lower work ethics but higher job satisfaction compared to non-permanent employees. Furthermore, Arifuddin's study (2002) among 350 auditors who work in a public accounting firm in Makassar, Indonesia, revealed the negative effect of work ethics on job satisfaction due to irregular salaries and limited opportunity for promotion for employees.

The effect of works ethics on organizational commitment can be moderated by fair or unfair treatment of employees which may cause satisfaction or dissatisfaction among them (Sharma, Borna \& Stearns, 2009). The satisfaction level of human beings towards fairness can be explained by the Equity theory (Locke, cited in Robbins, 2003). Based on the Equity theory, a satisfaction level of employees is dependent on a level of fairness received by them in a certain situation (Gibson et al., 2011).

\subsection{Relationship between Work Ethics and Organizational Commitment}

Widely accepted and clear organizational commitment may create a work environment that encourages social process, work regulation and ethical behaviour in an organization (Kaptein, 2008). Organization has to develop work ethics for controlling the behaviour of employees, which, eventually, will improve the loyalty of employees (Bruhn, 2009). Organizational commitment among employees will affect their job performance, thus it is important for the company to create a condition that will lead to organizational commitment among the employees (Valentine et al., 2011). Organizations that are concerned with work ethics will practice human resources management professionally, such as paying attention to job satisfaction, thereby creating a policy that will lead to organizational commitment among employees and motivate employees to have high job performance (Yousef, 2001). Work ethics has a strategic role in an organization because it will create organizational value, loyalty, and, ultimately, profit (Ali \& Al-Kazemi, 2007).

The positive effect of work ethics based on religious values on organizational commitment has been reported by many studies. Both Protestant work ethics (Williams \& Sandler, 1995) and Islamic work ethics (Yousef, 2000, 2001; Ali \& Al-Kazemi, 2007; Mohamed et al., 2010; Rokhman, 2010) have contributed to the high organizational commitment among employees. A study among 762 managers in Kuwait revealed that employee's work values influence their loyalty to the organization, while Arab expatriates have a greater organizational commitment compared to managers from Kuwait (Ali \& Al-Kazemi, 2007).

Work ethics may have either a positive or a negative effect on organizational commitment. Cullen et al. (2003), in their study among 411 employees in multinational companies in the USA, found a positive influence of a wise ethical climate and a negative influence of an egoist ethical climate on organizational commitment. Ethical climate principles have a positive influence on professional employees but have no effect on non-professional employees (Cullen et al., 2003). In addition, Islamic work ethics do not have any influence on employees' loyalty to organizations in Turkey (Uygur, 2009). A study by Sharma et al. (2009), among 204 furniture retailers in the USA, reported that fairness is important to create organizational commitment among employees.

Employees that remain working with the organization may have different types of commitment. There are three types of organizational commitment-affective commitment, continuance commitment and normative commitment (Allen \& Meyer, 1990). Affective commitment is the emotional attachment of employees to, and involvement with an organization. Continuance commitment pertains to those employees who expect to continue to work or leave the organization based on profit or loss considerations. Lastly, normative commitment concerns the employees who continue working in the organization due to a moral obligation (Allen \& Meyer, 1990).

Based on the previous review of the literature, two hypotheses are proposed as follows:

Hypothesis 1: Work ethics have a significant effect on job satisfaction

Hypothesis 2: Work ethics have a significant effect on organizational commitment

\section{Method}

Based on the previous review of literature, this study develops a conceptual framework, as shown in Figure 1. Three latent variables/constructs are in the framework, namely, work ethics, job satisfaction and organizational commitment, which are measured by eight, five and three indicators, respectively. Work ethics and organizational commitment use a reflective indicator, since the indicator is able to reflect these two latent variables (Ali, 1988), while job satisfaction uses a formative indicator because this indicator is able to construct or influence this latent variable (Robbins, 2003). Job satisfaction and organizational commitment are endogenous variables while work ethics is an exogenous variable. The definitions of the latent variables and their indicators are shown by Tables 1 and 2 , respectively. 


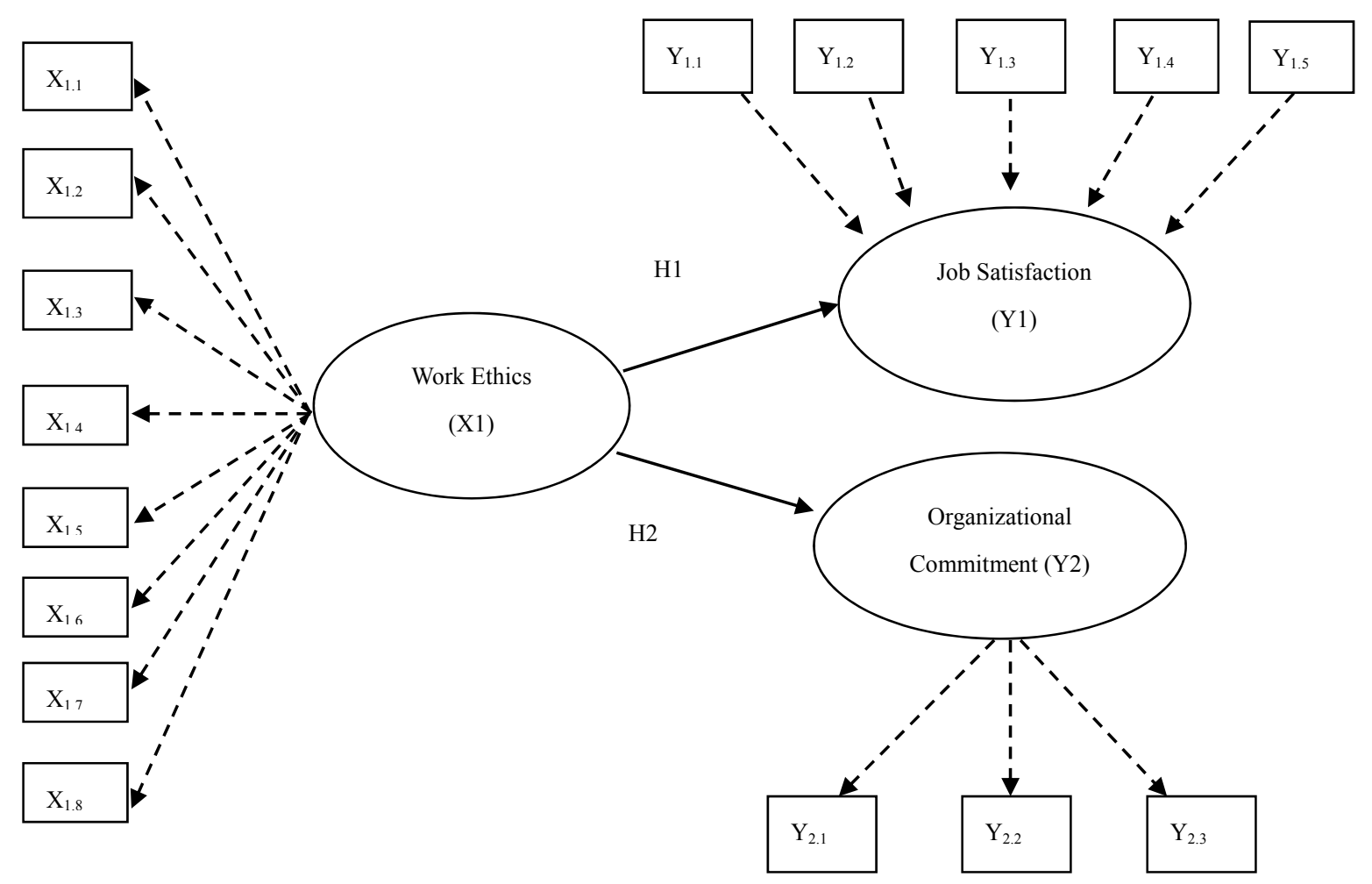

Figure 1. Conceptual framework

Table 1. The definition of latent variables

\begin{tabular}{lll}
\hline Latent Variables & Definition & Source \\
\hline Work Ethics (X1) & $\begin{array}{l}\text { A normative rule that contains the value system and moral principle as a guideline } \\
\text { for employees to do their work within the organization. }\end{array}$ & $\begin{array}{l}\text { Parboteeah, Chen, } \\
\text { Chen, Lee, \& Chung, 2010; } \\
\text { Ali, } 1988 .\end{array}$ \\
Job Satisfaction (Y1) & $\begin{array}{l}\text { Employees' attitudes or feelings towards enjoyment in their jobs given the current } \\
\text { remuneration provided by the company. }\end{array}$ & Luthans, 2006. \\
Organizational & $\begin{array}{l}\text { Employees' strong desire to remain as a member of the organization, try hard to meet } \\
\text { organizational expectations, uphold the values and objectives of the organization. }\end{array}$ & Allen \& Meyer, 1990. \\
\hline
\end{tabular}

Table 2. Latent variables, indicators and definition of the indicators

\begin{tabular}{|c|c|c|}
\hline $\begin{array}{l}\text { Latent } \\
\text { Variables/Source }\end{array}$ & Indicators & Definition \\
\hline \multirow{8}{*}{$\begin{array}{l}\text { Work Ethics (X1) } \\
\text { (Victor \& Cullen, } \\
\text { 1988; Ali, 1988) }\end{array}$} & Care $(\mathrm{X} 1.1)$ & $\begin{array}{l}\text { The sincere attitude of the employees towards people inside and outside the } \\
\text { organization. }\end{array}$ \\
\hline & Ethics Code (X1.2) & A decision made by the employees based on professional code of ethics. \\
\hline & Regulation (X1.3) & A set of rules on employees' working attitudes that must be obeyed. \\
\hline & Instrumental (X1.4) & Selfishness among employees towards the people within the organization. \\
\hline & Independence (X1.5) & Employees' personal moral beliefs based on considered principles. \\
\hline & Hard Work (X1.6) & Employees' attitude who always want to work. \\
\hline & Working as a Goal (X1.7) & Employees' attitude towards work that will lead to self-esteem. \\
\hline & Time Utilization (X1.8) & Employees' attitude towards productive work. \\
\hline
\end{tabular}




\begin{tabular}{|c|c|c|}
\hline Job Satisfaction (Y1) & Satisfaction with Salary (Y1.1) & Employees' satisfaction with remuneration provided by the organization. \\
\hline \multirow[t]{4}{*}{ (Luthans, 2006) } & $\begin{array}{l}\text { Satisfaction with Promotion } \\
\text { (Y1.2) }\end{array}$ & Employees' satisfaction with career opportunity provided by the organization. \\
\hline & $\begin{array}{l}\text { Satisfaction with Co-worker } \\
\text { (Y1.3) }\end{array}$ & Employees' satisfaction with support from co-workers in the organization. \\
\hline & $\begin{array}{l}\text { Satisfaction with Supervisor } \\
\text { (Y1.4) }\end{array}$ & Supervisors' ability to provide technical assistance and support. \\
\hline & $\begin{array}{l}\text { Satisfaction with job itself } \\
(Y 1.5)\end{array}$ & $\begin{array}{l}\text { Employees' satisfaction with job when the job is interesting and there is an } \\
\text { opportunity to learn and to take responsibility. }\end{array}$ \\
\hline $\begin{array}{l}\text { Organizational } \\
\text { Commitment (Y2) }\end{array}$ & Affective Commitment (Y2.1) & $\begin{array}{l}\text { The strong desire of the employees to continue working with the organization } \\
\text { because they want to do so. }\end{array}$ \\
\hline \multirow[t]{2}{*}{ (Allen \& Meyer, 1990) } & $\begin{array}{l}\text { Continuance Commitment } \\
\text { (Y2.2). }\end{array}$ & $\begin{array}{l}\text { Employees' expectation to continue to work with or leave the organization } \\
\text { based on profit or loss consideration. }\end{array}$ \\
\hline & Normative Commitment (Y2.3). & $\begin{array}{l}\text { Remain working with organization due to unethical feeling of leaving the } \\
\text { organization. }\end{array}$ \\
\hline
\end{tabular}

In order to test the hypothesis, research has been conducted in 2010 on the largest and the fastest growing Sharia Bank in Indonesia, which was established in 1999. The bank has been classified as a top bank for customer loyalty and has received several awards, such as the best Islamic Bank in Indonesia. The research location is in West Kalimantan. The Sharia Bank opened its first branch in West Kalimantan in 2002. By 2012, the bank had five branches located in five cities namely Pontianak, Mempawah, Sintang, Nanga Pinoh and Sanggau.

This study uses primary data obtained through a self-administered questionnaire. The respondents for this research were all permanent employees working in the five branches of the Sharia Bank, numbering some 78 employees. Several respondents were purposively selected as key-informants for in-depth interviews. The in-depth interviews were conducted to explore the relationship mechanism between work ethics, job satisfaction and organizational commitment. The in-depth interviews were carried out by researchers utilizing an interview guide.

A five-point Likert scale was utilized to measure each indicator of latent variables ranging from 1 (very poor) to 5 (very good). Indicators in this study are a modified version of the indicators developed by Victor \& Cullen (1988), and Ali (1988) for work ethics; Luthans (2006) for job satisfaction, and Allen \& Meyer (1990) for organizational commitment. The data were analysed using the Partial Least Squares (PLS) approach and processed using Smart PLS and PLS-Graph software. PLS is a structural equation model (SEM) based on components or variance. Percentage distribution is also used to analyse the characteristics of the respondents.

A convergent validity test was conducted to test the potential indicators of all constructs, while a composite reliability test carried out to test the constructs used two reflective indicators-work ethics and organizational commitment. The convergent validity test was used to select valid/significant indicators that could be used to measure the constructs. Meanwhile, the composite reliability test was utilized to test the reliability of the indicators by measuring the correlation between the construct and their respective indicators. The indicators will be reliable if the correlation coefficient is equal to or greater than $0.70\left(\rho_{c} \geq 0.70\right)$ (Chin, 1998).

\section{Results}

\subsection{Statistical Results}

Most of the respondents are young or less than 30 years of age ( 83 per cent), female ( 52 per cent) and have a first degree ( 88 per cent) (Table 3 ). The bank recruits are mainly employees with first degree education because they find it easier to understand the work system and to adjust with changing environment in the organization for customer satisfaction. More than 50 per cent of the respondents are single and have been working for two years or less.

The results of the data analysis show that the mean scores for work ethics, job satisfaction and organizational commitment are 3.64, 3.41 and 4.08, respectively. This indicates that, on average, the respondents have high work ethics, high job satisfaction and high organizational commitment. Table 4 presents the convergent validity test results for valid indicators only, or those indicators having a t-value of 1.96 or more. The composite reliability test for the reflective indicators show that the coefficient correlation between each construct and the respective indicator is greater than 0.70 meaning that the indicators are reliable for measuring the constructs 
(Table 5). Moreover, the coefficients of path analysis show that the effect of work ethics on job satisfaction is negative (-0.012) and non-significant while the effect of work ethics on organizational commitment is positive (0.36) and significant (Table 6).

Table 3. Characteristics of the respondents

\begin{tabular}{|c|c|c|}
\hline Characteristics & Frequency & Percentage $(\%)$ \\
\hline \multicolumn{3}{|l|}{ Age (year) } \\
\hline$\leq 25$ & 30 & 39 \\
\hline $26-30$ & 34 & 44 \\
\hline $31-35$ & 6 & 8 \\
\hline $36-40$ & 5 & 6 \\
\hline$\geq 41$ & 2 & 3 \\
\hline \multicolumn{3}{|l|}{$\operatorname{Sex}$} \\
\hline Male & 37 & 48 \\
\hline Female & 40 & 52 \\
\hline \multicolumn{3}{|l|}{ Highest Educational Attainment } \\
\hline Completed Tertiary Education & 1 & 1 \\
\hline Diploma & 7 & 9 \\
\hline First Degree & 68 & 88 \\
\hline Master Degree & 1 & 1 \\
\hline \multicolumn{3}{|l|}{ Marital Status } \\
\hline Married & 33 & 43 \\
\hline Single & 44 & 57 \\
\hline \multicolumn{3}{|l|}{ Work duration (year) } \\
\hline$\leq 2$ & 53 & 69 \\
\hline $3-5$ & 14 & 18 \\
\hline $6-8$ & 4 & 5 \\
\hline$\geq 9$ & 6 & 8 \\
\hline
\end{tabular}

Source: Field survey, 2010.

Table 4. Convergent validity test results for valid indicators

\begin{tabular}{llll}
\hline Latent variables/Constructs & Valid Indicators & Loading Factor & t- Statistics \\
\hline \multirow{2}{*}{ Work Ethics } & $\mathrm{X} 1.1$ & 0.446 & 6.945 \\
& $\mathrm{X} 1.2$ & 0.578 & 7.423 \\
& $\mathrm{X} 1.3$ & 0.761 & 12.005 \\
& $\mathrm{X} 1.4$ & 0.545 & 8.019 \\
& $\mathrm{X} 1.6$ & 0.788 & 28.279 \\
Job Satisfaction & $\mathrm{X} 1.7$ & 0.603 & 10.069 \\
& $\mathrm{X} 1.8$ & 0.66 & 15.204 \\
& $\mathrm{Y} 1.1$ & 0.474 & 4.108 \\
& $\mathrm{Y} 1.3$ & 0.425 & 2.623 \\
\hline
\end{tabular}




\begin{tabular}{llll}
\hline & Y1.5 & 0.341 & 2.654 \\
Organizational Commitment & Y2.1 & 0.874 & 39.575 \\
& Y2.2 & 0.858 & 36.42 \\
\hline
\end{tabular}

Table 5. Composite reliability test results

\begin{tabular}{lll}
\hline Latent variables/Constructs & Coefficient correlation $\left(\rho_{c}\right)$ & Note \\
\hline Work Ethics & & Reliable \\
Organizational Commitment & 0.822 & Reliable \\
\hline
\end{tabular}

Table 6. Hypothesis test results

\begin{tabular}{llll}
\hline Direction of Causality & Path Coefficient & Std. Error (Bootstrap) & t-statistics \\
\hline Work Ethics -> Job Satisfaction & & & 0.111 \\
Work Ethics -> Organizational Commitment & 0.012 & 0.104 & $7.116^{*}$ \\
\hline
\end{tabular}

Notes: Asterisk $(*)$ denotes significant at the 5 per cent level.

\subsection{Qualitative Results Based on In-Depth Interview with Key Informants}

\subsubsection{The Effect of Work Ethics on Job Satisfaction}

Employees in the company have had good work ethics. Good work ethics among the employees is due to work ethics values, which are the same as their religious values. Good work ethics among the employees are shown by the employees who never receive a reminder letter; who provide services to the customers based on the company standard; who help each other in doing their job; and who provide feedback to the company. The good work ethics among the employees is also indicated by doing tasks according to the code of ethics and regulations, placing the company's interests over personal interests, working hard to achieve the target, and using the time effectively.

Meanwhile, job satisfaction is influenced by the relationships among employees and between employees and their supervisors. Employees help and support each other, which is very helpful in completing their tasks. Supervisors are willing to listen to feedback from the employees. All employees under the same supervisor are treated equally. Rewards are given to any employee who has done a good job, while punishment is given to any employee who has made a mistake. Job satisfaction is also influenced by task delegation, in which the company places the right people in the right place. Employees are given tasks and responsibilities based on their talents and interests, work duration and education level. Ultimately, employees feel comfortable, which encourages them to maximize their job performance.

Nevertheless, work ethics and job satisfaction are two different things and they are not necessarily related. Having good work ethics does not necessarily make the employees satisfied with the policies relating to them. Some of the key informants explain unfairness in the company by comparing their salary with the salary of another employee who does the same task as them at another company. For instance, the salary for the employees in their office having less than two years working experience and first degree education is Rp. 2.1 million per month, while the salary for employees at the other company having the same work experience and diploma education is Rp. 2.8 million per month. Moreover, in their office, overtime payment is Rp. 12,500 per hour without meal allowance if the employees work less than three hours a day, while overtime payment at the other company is Rp 16,000 per hour plus $\mathrm{Rp} 25,000$ meal allowance regardless of the length of overtime a day.

\subsubsection{The Effect of Work Ethics on Organizational Commitment}

Work ethics has a significant and positive effect on organizational commitment. This means that higher work ethics will increase organizational commitment while lower work ethics will reduce organizational commitment. The positive effect of work ethics on organizational commitment can be attributed to four reasons. Firstly, work ethic values that are compatible with the employee's religious beliefs and expectations create a strong desire for 
the employee to remain working with the company. The employee also tries their best to work according to the company's expectations and accepts corporate values and objectives.

Secondly, the company cares about the employees. The company develops communication among employees and between employees and the higher ranking officials through formal and informal meetings. The company also treats employees as a family, which makes the employees feel a meaningful relationship with the company. This non-material compensation creates loyalty among the employees to the company. Moreover, this compensation will not necessarily be obtained by the employees if they work at other companies.

Thirdly, the company has a good reputation, as indicated by the rapid growth of the bank branches, the majority (95 per cent) of those who perform hajj in West Kalimantan are customers of this bank and the many awards received by the bank. Thus, the employees are proud of working for the company. Lastly, employees care about the company, such as by obeying professional codes of ethics in terms of keeping any official business confidential; keeping the company's good image for the sustainability of the company; and working hard to achieve the performance target.

\section{Discussion and Conclusion}

The main objective of this study is to examine the effect of work ethics on job satisfaction and organizational commitment. The findings show that the effect of work ethics on job satisfaction is negative and not significant. This finding is similar to the findings in Turkey, whereby work ethics is measured by self-interest (Elci \& Alpkan, 2009); in Indonesia, which is due to non-regular salaries and the lack of opportunity for employees for promotion (Arifuddin, 2002); in Japanese manufacturing companies in the USA (Elkins, 2007), and in Pakistan among employees in private and government organizations (Ahmed et al., 2012). The findings in this study are different from many of the previous findings inasmuch as the effect of work ethics on job satisfaction is positive and significant (eg., Yousef, 2000; Mohamed et al., 2010; Rokhman, 2010; Cullen et al., 2003; Koh \& Boo, 2004; Okpara \& Wynn, 2008).

The negative and non-significant effect of work ethics on job satisfaction could be due to the employees who are less satisfied with their salary compared to employees in other companies. Based on the Equity theory (Gibson et al., 2011), these employees are not satisfied with their salary due to a certain situation. They feel they are unfair, as their education is higher but their salary is lower compared to those in other companies. Work ethics is more about moral values while job satisfaction may include both moral and economic values. Nevertheless, job dissatisfaction among the employees does not reduce their work ethics and organizational commitment.

The findings in this study show a positive and significant effect for work ethics on organizational commitment. This findings support some of the previous studies (Williams \& Sandler, 1995; Yousef, 2000; 2001; Ali \& Al-Kazemi, 2007; Mohamed et al., 2010; Rokhman, 2010). Organizational commitment at the Sharia Bank seems to be dominated by affective commitment (Allen \& Meyer, 1990). This is indicated by the emotional attachment of employees to the Sharia Bank due to work ethics, which are the same as their religious beliefs, the company cares about employees, proud of being employees at this bank and the employees care about the bank.

To conclude, this study shows that work ethics are very important for organizational commitment but that they cannot automatically create high job satisfaction. Good work ethics are able to create a high organizational commitment among the employees, which encourages them to remain working with the bank even though they are less satisfied with their job. Since job satisfaction may include economic values, a fair salary is necessary for job satisfaction. This study recommends that the company should consider an external situation, such as the salary offered by the company's competitors for reducing the salary gap to enhance the feeling of fairness and job satisfaction among the employees. Furthermore, this study suggests further research to explore various factors relating to work ethics, such as job stress, career success, job security and social responsibility. Fairness needs to be considered as a moderating variable linking work ethics with job satisfaction. A similar study also needs to be conducted at conventional banks. However, the findings in this study need to be interpreted carefully due to the small sample size, and the fact that the respondents are only from one company and have little working experience.

\section{Acknowledgements}

The authors would like to gratefully acknowledge the anonymous referees for their helpful comments on an earlier version of the paper. Any remaining errors or omissions rest solely with the authors of this paper. The second author would like to thank the Faculty of Economics, Universitas Tanjungpura, which seconded her temporarily to the Faculty of Economics and Business, UNIMAS. 


\section{References}

Ahmed, B., Shad, I., Mumtaz, R., \& Tanveer, Z. (2012). Organizational ethics and job satisfaction: Evidence from Pakistan. African Journal of Business Management, 6(8), 2966-2973.

Ali, A. J. (1988). Scaling an Islamic work ethic. The Journal of Social Psychology, 128(5), 575-583. http://dx.doi.org/10.1080/00224545.1988.9922911

Ali, A. J., \& Azim, A. (1995). Work ethic and loyalty in Canada. The Journal of Social Psychology, 135(1), 3137. http://dx.doi.org/10.1080/00224545.1995.9711399

Ali, A. J., \& Al-Kazemi, A. A. (2007). Islamic work ethic in Kuwait. Cross Cultural Management: An International Journal, 14(2), 93-104. http://dx.doi.org/10.1108/13527600710745714

Allen, N. J., \& Meyer, J. P. (1990). The measurement and antecedents of affective, continuance and normative commitment to the organization. Journal of Occupational Psychology, 63(1), 1-18. $\mathrm{http}: / / \mathrm{dx}$. doi.org/10.1111/j.2044-8325.1990.tb00506.x

Arifuddin. (2002). The effect of work ethics on job satisfaction, organizational commitment and willingness to quit from job at the Public Accountants Office, Makassar (Pengaruh Kecocokan Etika Terhadap Kepuasan Kerja, Komitmen Organisasi dan Keinginan Berpindah Pada Kantor Akuntan Publik di Makasar). Master Thesis. Graduate Programme in Accounting Science, Universitas Diponegoro, Semarang. Retrieved from http://eprints.undip.ac.id/9436/1/2002MAK1875.pdf

Bruhn, J. G. (2009). The functionality of gray area ethics in organizations. Journal of Business Ethics, 89(2), 205-214. http://dx.doi.org/10.1007/s10551-008-9994-7

Chileshe, N., \& Haupt, T. C. (2010). The effect of age on the job satisfaction of construction workers. Journal of Engineering, Design and Technology, 8(1), 107-118. http://dx.doi.org/10.1108/17260531011034682

Chin, W. W. (1998). The partial least squares approach to structural equation modelling. In G. A. Marcoulides (Ed.), Modern methods for business research (pp. 295-336). Mahwah, NJ: Lawrence Erlbaum Associates, Inc.

Coldwell, D. A., Bilsberry, J., Meurs, N., \& Marsh, P. J. G. (2008). The Effects of Person-Organization Ethical Fit on Employee Attraction and Retention: Towards a Testable Explanatory Model. Journal Business Ethics, 78(4), 611-622. http://dx.doi.org/10.1007/s10551-007-9371-y

Cullen, J. B., Parboteeah, K. P., \& B. Victor. (2003). The effects of ethical climates on organizational commitment: a two-study analysis. Journal of Business Ethics, 46(2), 127-141. http://dx.doi.org/10.1023/A:1025089819456

Elci, M., \& Alpkan, L. (2009). The impact of perceived organizational ethical climate on work satisfaction. Journal of Business Ethics, 84, 297-311. http://dx.doi.org/10.1007/s10551-008-9709-0

Elci, M., Sener, I., \& Alpkan, L. (2011). The impact of morality and religiousity of employees on their hardworking behaviour. Procedía Social and Behavioural Sciences, 24, 1367-1377. http://dx.doi.org/10.1016/j.sbspro.2011.09.135

Elkins, S. L. (2007). Job satisfaction and work ethic among workers in a Japanese manufacturing company located in the United States. PhD Thesis, The University of Tennessee-Knoxville. Retrieved from http://etd.utk.edu/2007/ElkinsSam.pdf

Gibson, J. L., Ivancevich, J. M., Donnelly, J. H., \& Konopaske, R. (2011). Organizations: Behaviour, Structure, Processes (14th ed.). Boston: McGraw-Hill.

Gu, Z., \& Siu, R. C. S. (2009). Drivers of job satisfaction as related to work performance in Macao casino hotels: An investigation based on employee survey. International Journal of Contemporary Hospitality Management, 21(5), 561-578. http://dx.doi.org/10.1108/09596110910967809

Jewell, L. N. (1998). Contemporary Industrial/Organizational Psychology (3rd ed.). South-Western: Cengage Learning.

Kaptein, M. (2008). Developing and testing a measure for the ethical culture of organizations: the corporate ethical virtues model. Journal of Organizational Behaviour, 29(7), 923-947. http://dx.doi.org/10.1002/job.520

Khan, B., Farooq, A., \& Hussain, Z. (2010). Human resource management: An Islamic perspective. Asia-Pacific Journal of Business Administration, 2(1), 17-34. http://dx.doi.org/10.1108/17574321011037558 
Koh, H. C., \& Boo, E. H. Y. (2004). Organisational ethics and employee satisfaction and commitment. Management Decision, 42(5), 677-693. http://dx.doi.org/10.1108/00251740410538514

Kurpis, L. V., Begiri, M. S., \& Helgeson, J. G. (2008). The effects of commitment to moral self-improvement and religiousityon ethics of business students. Journal of Business Ethics, 80, 447-463. http://dx.doi.org/10.1007/s10551-007-9430-4

Leat, M., \& El-Kot, G. (2009). Interpersonal trust at work, intrinsic motivation, work-related tension and satisfaction in Egypt. International Journal of Workplace Health Management, 2(2), 180-194. http://dx.doi.org/10.1108/17538350910970237

Locke, E. A., Latham, G. P., \& Erez, M. (1988). The determinants of goal commitment. The Academy of Management Review, 3(1), 23-39.

Luthans, F. (2006), Organizational Behaviour (11th ed.). New York: McGraw-Hill.

Mohamed, N., Karim, N. S. A., \& Hussein, R. (2010). Linking Islamic workethics to computeruse ethics, jobsatisfaction and organisationalcommitment in Malaysia. Journal of Business Systems, Governance and Ethics, 5(1), 13-23.

Okpara, J. O., \& Wynn, P. (2008). The impact of ethical climate on job satisfaction, and commitment in Nigeria:Implications for management development. Journal of Management Development, 27(9), 935-950. http://dx.doi.org/10.1108/02621710810901282

Parboteeah, K. P., Chen, H. C., Lin, Y. T., Chen, I. H., Lee, A. Y. P., \& Chung, A. (2010). Establishing organizational ethical climates: How do managerial practices work? Journal of Business Ethics, 97, 559611. http://dx.doi.org/10.1007/s10551-010-0527-9

Robbins, P. S. (2003). Organizational Behavior (10th ed.). New Jersey: Pearson Education, Inc.

Rokhman, W. (2010). The effect of Islamic work ethics on work outcomes. Electronic Journal of Business Ethics and Organization Studies, 15(1), 21-27.

Sharma, D., Borna, S., \& Stearns, J. M. (2009). An investigation of the effects of corporate ethical values on employee commitment and performance: Examining the moderating role of perceived fairness. Journal of Business Ethics, 89(2), 251-260. http://dx.doi.org/10.1007/s10551-008-9997-4

Uygur, S. (2009). The Islamic work ethic and the emergence of Turkish SME owner-managers. Journal of Business Ethics, 88(1), 211-225. http://dx.doi.org/10.1007/s10551-009-0107-z

Valentine, S., \& Fleischman, G. (2008). Ethics programs, perceived corporate social responsibility and job satisfaction. Journal of Business Ethics, 77(4), 159-172. http://dx.doi.org/10.1007/s10551-006-9306-z

Valentine, S., \& Barnett, T. (2007). Perceived organizational ethics and the ethical decisions of sales and marketing personnel. Journal of Personal Selling \& Sales Management, 27(4), 373-388. http://dx.doi.org/10.2753/PSS0885-3134270407

Valentine, S., Godkin, L., Fleischman, G. M., \& Kidwell, R. (2011). Corporate ethical values, group creativity, job satisfaction and turnover intention: The impact of work context on work response. Journal of Business Ethics, 98(3), 353-372. http://dx.doi.org/10.1007/s10551-010-0554-6

Victor, B., \& Cullen, J. (1988). The organizational bases of ethical work climates. Administratif Science Quarterly, 33(1), 101-125. http://dx.doi.org/ 10.2307/2392857

Williams, S., \& Sandler, R. L. (1995). Work values and attitudes: Protestant and Confucian Ethics as predictors of satisfaction and commitment. Research and Practice in Human Resource Management, 3(1), 1-13.

Yousef, D. A. (2001). Islamic work ethic - a moderator between organizational commitment and job satisfaction in a cross-cultural context. Personnel Review, 30(2), 152-169. http://dx.doi.org/10.1108/00483480110380325

Yousef, D. A. (2000). The Islamic work ethic as a mediator of the relationship between locusof control, role conflict and role ambiguity - a study in an Islamic country setting. Journal of Managerial Psychology, 15(4), 283-302. http://dx.doi.org/10.1108/02683940010330966 


\section{Copyrights}

Copyright for this article is retained by the author(s), with first publication rights granted to the journal.

This is an open-access article distributed under the terms and conditions of the Creative Commons Attribution license (http://creativecommons.org/licenses/by/3.0/). 